\author{
JUHÁSZ ÁGNES*
}

\title{
A szerződések tipizálásáról és a franchise szerződésről az új Ptk. föbizottsági javaslata kapcsán
}

Atipikus szerződések - franchise - Kodifikációs Főbizottság - új Ptk.

A magánjogban az egyes szerződések csoportosítására többféle elhatárolási szempont ismert. Különbséget szokás tenni nevesített (ezen belül tipikus és atipikus), illetőleg nem nevesített (vegyes és de facto) szerződések között. A nevesített szerződések körén belül a tipikus és atipikus szerződések közötti elhatárolás alapját alapvetően az adott szerződés Ptk.-beli nevesítettsége képezi.

A Ptk. egyes szerződéseit tekintve azonban két fontos megállapítást kell tennünk: a Ptk.-ban szabályozott szerződések a törvény által meghatározott, teljesen letisztult formában csak nagyon ritkán fordulnak elő a gyakorlati életben. Annál gyakoribb viszont, hogy az egyes szerződések, szerződéstípusok elemei egymással összekapcsolódva, sajátos módon keveredve vegyes szerződés formájában hoznak létre újabb szerződéses alakzatot, ezzel némiképp elmosva a klasszikus szerződési alaptípusok határait.

A vegyes jellegü szerződések számának növekedése mellett a másik érezhető tendencia az atipikus szerződések tipizálódása. Tény, hogy a tipikus és atipikus szerződések közötti elhatárolás - legalábbis a Ptk. általi nevesítés szempontjából - eddig is csupán viszonylagos volt, hiszen az idők során a magánjog fejlődésének eredményeként bizonyos - korábban nem nevesített - szerződések utóbb a Ptk.-ba integrálódva nevesítetté váltak. Ez a folyamat az utóbbi évtizedben - a polgári jogi kodifikációs munkálatokkal párhuzamosan - olyannyira felerősödött, hogy az új Ptk. legújabb (2012 februárjában közzétett) szövegtervezete szerint a jelenleg atipikusként emlegetett szerződések nagy része a kódex részévé válna.

Jelen tanulmányban az atipikus szerződések Ptk.-ba történő beemelésével kapcsolatos vitákat tekintem át röviden az érvek és ellenérvek felvonultatásával, különös tekintettel arra, hogy a korábban egyértelműen „mellőzésre ítélt” franchise szerződés a jogalkotó szándéka szerint 2012-ben már helyet kapna a kódex rendelkezései között.

* Dr. Juhász Ágnes egyetemi tanársegéd, Miskolci Egyetem Állam- és Jogtudományi Kar, Polgári Jogi Tanszék, civagnes@uni-miskolc.hu. 


\section{Az atipikus szerződésekről általában}

A különböző atipikus szerződésekkel foglalkozó kutatások manapság különösen népszerüek, hiszen a Ptk. „Egyes szerződések” könyvében nevesített szerződéstípusokra vonatkozóan viszonylag letisztult képet mutatnak, miközben a gyakorlati életben újabb és újabb szerződések jelennek meg, amelyek egyértelmüen egyik típus szabályanyaga alá sem rendelhetők. Mégis mi alapján tekinthetünk egy adott szerződést vegyes jellegünek, tipikusnak vagy atipikusnak? A szerződések ez irányú tipizálásával kapcsolatos vizsgálódások hazánkban hosszú múltra tekintenek vissza.

Az Mtj. kapcsán már a két világháború közötti időszakban találkozunk az „atipikus”, illetve a „nem tipizált” kifejezéssel, bár ezek jelentéstartalma a maival még közel sem tekinthető azonosnak, és azok vizsgálata sem feltétlenül a mai szempontok szerint volt jellemző. ${ }^{1}$ Fürst például a magánjogi kódexben nem nevesített szerződésekkel állítja párba a nem tipizált szerződéseket, amelyeken belül különbséget tesz innominát (pl. kartellszerződés) és típuskombinációs vegyes szerződések (pl. házmesteri szerződés, szanatóriumi szerződés) között. ${ }^{2}$ Szladits tipikus és atipikus szerződéseket különböztet meg, melyek között egyfajta átmenetet képeznek az ún. vegyes szerződések. Ezek több tipikus szerződés elemeit vegyítik, vagy pedig egyes tipikus és atipikus szerződések elemeit foglalják magukban. ${ }^{3}$

Az 1970-es években az „atipikus” jelző egyszerűen azokat a szerződéseket jelölte, amelyek a tipikustól (vagyis a Ptk.-ban rögzítettektől) valamilyen módon eltértek. Móry László például az együttmüködési szerződést arra hivatkozással tekinti vegyes jellegű atipikus szerződésnek, hogy az, mint többoldalú együttműködési jogviszony nem felel meg a Ptk. egyik nevesített szerződéstípusa jellemzőinek sem. ${ }^{4}$ Megjegyzendő, hogy ezek a szerződések a mai értelemben vett „atipikusságnak” nem feltétlenül lennének minden esetben megfeleltethetők ${ }^{5}$, sőt ekkortájt még önmagában a szerződések tipizálásának módja, szükségszerüsége is kérdéseket vetett fel. ${ }^{6}$

A gazdasági élet, a piaci viszonyok megváltozásának, felpezsdülésének köszönhetően új gazdasági folyamatok jelentek meg, amelyek új szerződéses megoldásokat kívántak. Ennek eredményeként, az 1990-es évektől kezdve az újonnan megjelenő jogi konstrukciók egyre inkább a figyelem középpontjába kerültek, mígnem a polgári jog egyes szerződésekkel foglalkozó területe ismét virágozni kezdett, és az atipikus szerződésekkel foglalkozó tanulmányok, szakcikkek népszerüsége máig is töretlen.

Az atipikus szerződésekhez kapcsolódó egyik első részletesebb elemzés Miskolczi Bodnár Péter nevéhez füződik, aki az említett fogalmat negatív irányból közelítve úgy határozta meg, mint olyan szerződések összességét, amelyek legfőbb sajátossága,

1 Erről lásd bővebben: PAPP Tekla: Az atipikus szerződések és a Magyar Magánjogi Törvényjavaslat, In: Jogtudományi Közlöny, 64. évf. (2009) Különszám, 35-39.

2 Fürst László: A magánjog szerkezete, Grill Károly Kiadóvállalata, Budapest, 1934, 432.

Szladits Károly: A magyar magánjog vázlata, Budapest, 1933, 175-176.

4 MóRY László: Az együttműködési szerződés, Jogtudományi Közlöny, 22. új évf. (1967), 675.

5 DıósDI György: Atipikus szerződések a bírósági gyakorlatban - egy felmérés tapasztalatai, Jogtudományi Közlöny, 26. évf. (1971) 2. 89-94.

6 VÉKÁs Lajos: A szerződéstipizálás válságjelenségeiről, In: Jogtudományi Közlöny, 30. évf. (1975) 12. 699_ 706. 
hogy nem sorolhatók a Ptk. szerinti egyetlen szerződéstípusba sem. ${ }^{7}$ A szerződések ilyesfajta csoportosítása azonban meglehetősen viszonylagos, hiszen egy idesorolt szerződés a Ptk.-ba illesztéssel, kodifikációval bármikor elveszítheti atipikus jellegét. Miskolczi az atipikus szerződések körén belül megkülönböztet egyedi (egyszeri), vegyes és nevesített atipikus szerződéseket, ez utóbbi kategórián belül helyezve el a lízing-, a faktoring- és a franchise szerződést.

Az atipikus szerződések átfogó, monografikus szintű elemzésére Papp Tekla tett kísérletet, melynek során egyrészt rendszert állított fel a szerződések csoportosítására nézve, másrészt pedig összefoglalta azokat a föbb jellemvonásokat, amelyek egy adott szerződést atipikussá tesznek, azaz „kiszorítanak” a Ptk. klasszikus, tipizált szerződési rendszeréből. ${ }^{8}$ E szerződések körébe sorolandó például a szindikátusi szerződés, a timesharing-szerződés, a koncessziós szerződés, a lízing- és faktoringszerződés, valamint a licencia- és a merchandising-szerződés. A Papp Tekla által felállított csoportosítást követve ${ }^{9}$ tehát a magánjogi szerződéseken belül különbséget tehetünk nevesített és nem nevesített szerződések között, elöbbi csoportba tartoznak a tipikus (a Ptk. „Egyes szerződések” címe alatt szabályozott), valamint az atipikus (a Ptk.-ban szabályozottaktól eltérő) kontraktusok, míg a nevesítetlen szerződések körét a vegyes és de facto innominát megállapodások alkotják.

Az említett elhatárolás egyik fö eleme az atipikus és vegyes szerződések közötti határ megvonása; annak rögzítése, hogy a két kategória semmiképpen sem esik egybe. Papp Tekla ugyanakkor arra is felhívja a figyelmet, hogy az említett két csoport közötti határvonal napjainkban kissé összemosódni látszik, amennyiben megjelennek olyan, általa „ál-atipikusnak” nevezett szerződések, amelyek látszólag ugyan megfelelnek az atipikus szerződések kritériumainak, közelebbröl megvizsgálva azonban azok vagy a Ptk. szerinti klasszikus rendszerbe illeszthetők be, vagy éppen vegyes szerződésként foghatók fel (pl. disztribútori szerződés, dealeri szerződés, outsourcing, befektetési szerződés). ${ }^{10} \mathrm{Az}$ atipikus szerződések többségét jellemzi ugyanis például az idegen nyelvű (eredetű) megnevezés és hagyományosan a külföldi (jogalkotási és joggyakorlati) minták alapul vétele, az alapvetően nem kötelező, de annál inkább szokásos írásbeliség, valamint - a jogviszony egyik pólusán - a gazdálkodó szervezet részvétele és a szerződés tartós jogviszonyt keletkeztető jellege.

A tipikus és atipikus szerződések - alapvetően a Ptk.-hoz való viszonyon nyugvó - elhatárolásához képest a fenti értelemben atipikusként felfogott szerződések körén belül további megkülönböztetés alapjául szolgálhat a szerződések tartalmi jellegű vizsgálata. Ennek alapján beszélhetünk „tipikus atipikus” szerződésekről, amelyek a Ptk.-ban ugyan nem nyertek nevesítést (vagyis kodifikációs szempontból atipikusak), azonban más jogszabály nevesíti őket, önálló szerződésként jelennek meg, állandó-

7 Miskolczı BodnÁR Péter: Atipikus szerződések (Lízing, faktoring, franchise), Gazdaság és Jog, 5. évf. (1997) 1. sz. 3.

8 PAPp Tekla: Atipikus szerződések, Szegedi Egyetem, Állam- és Jogtudományi Kar, Szeged, 2006.

9 A szerződések tipizálására nézve lásd még: Bínó György: Szerződési alaptípusok, Novotni Alapítvány, Miskolc, 2010.

10 PAPP Tekla: Atipikus szerződések a magyar magánjogban, Scientia luris - Magyar-Román Jogtudományi Közlöny, 2011/2. sz. 64. és PAPP Tekla: Fejlődési tendenciák az atipikus szerződések területén, Gazdaság és Jog, 17. évf. (2009) 9. sz. 9. 
sult és önálló karakterjegyekkel bírnak. Idesorolható például a koncessziós szerződés, a közraktári szerződés, az önálló kereskedelmi ügynöki szerződés és a timesharingszerződés, de szintén itt kell megemlíteni az iparjogvédelem köréből a licenciaszerződést, amelynek szabályai szintén a Ptk. rendszerén kívül kerülnek rögzítésre. ${ }^{11} \mathrm{Az}$ atipikus szerződések körén belül szintén önálló csoportot képeznek a jogszabályban egyáltalán nem szabályozott szerződések, így a lízing-, a faktoring-, a franchising-, a befektetési és a merchandising-szerződés. ${ }^{12}$

$A z$ atipikus szerződések kialakulása, léte, a gazdasági és társadalmi viszonyok változása mind-mind arra kényszerítették a jogalkotót, hogy megoldást találjon az utóbbi évtizedben egyre gyakoribbá váló szerződéses konstrukciók szabályozására, így az új Ptk. kodifikációs előmunkálatai során az atipikus szerződések Ptk.-ba illesztésének kérdése aktuálissá és szükségszerüen megválaszolandóvá vált. A tanulmány következő pontjában a teljesség igényére való törekvés nélkül villantom fel az atipikus szerződések kodifikálásával kapcsolatban megfogalmazott egyes álláspontokat, ${ }^{13}$ azzal, hogy a beilleszthetőség kérdésében a 2009-ben elfogadott, azonban végül hatályba nem lépett Ptk. szövegéhez képest a 2012-ben nyilvánosságra hozott bizottsági szövegtervezetben jelentős változások tapasztalhatók.

\section{Az atipikus szerződések kodifikálásáról}

Az egyes atipikus szerződések Ptk.-ba illesztése a kodifikációs folyamat alatt folyamatos vitákat generált. Az ilyen szerződések fogalmi körülhatárolása már önmagában is problémaként jelentkezik, azonban ez a megállapítás különösen igaz (volt) a franchise esetén. Csécsy György már az 1990-es évek közepén aggályait fogalmazta meg a franchise szerződés definiálhatóságával kapcsolatosan, tekintettel arra, hogy a jogi és közgazdasági elemek keveredése a fogalomalkotást is több szempontúvá, de mindenekelőtt meglehetősen nehézkessé teszi. ${ }^{14}$

A franchise kapcsán a definiálás nehézségeit bőven meghaladják a szerződés legfőbb jellemvonásainak meghatározása során felmerülő problémák, noha a fő jellemzők körvonalazása alapvető feltétele az említett szerződés Ptk.-ba történő integ-

11 Érdemes megjegyezni, hogy a licenciaszerződést Csécsy György tipikus szerződésként fogja fel, tekintettel annak jogszabályi rögzítettségére, vagyis ez esetben a tipikus és atipikus szerződések közötti elhatárolást nem a Ptk.-beli, hanem általában a jogszabályi rögzítettség képezi. Lásd Csécsy György: Atipikus szerződések az iparjogvédelem körében, In: Facultas Nata: Ünnepi tanulmányok a miskolci jogászképzés 25. évfordulójára, Miskolc, 2006, 71.

12 A tipikus és atipikus szerződések közötti tartalmi elhatárolást Barta Judit a Szegeden, 2011. december 8-án megrendezésre került „Atipikus szerződések - hallgatói fórum” keretében elhangzott előadásában ismertette.

13 A franchise kodifikálásával kapcsolatos gyakorlati érveket lásd: FugLINSZKY Ádám: A franchise szerződés helye a szerződési rendszerben, „megérett-e” a kodifikációra a franchise, In: A Polgári Jogi Tudományos Diákkör Évkönyve, 1999-2000, ELTE, Budapest, 2001, 81-104. és OsvÁTH Ildikó: Az atipikus szerződések helye a polgári jogi kodifikációban, Publicationes Universitatis Miskolciensis, Sectio Juridica et Politica, Tomus XXIV., (2006), 457-468.

14 CsÉcsy György: Adalékok a franchise fogalmának meghatározásához és a franchise szerződésekhez, Jogtudományi Közlöny, 3. évf. (1995) 5. sz. 228., CsÉcsy György: A franchise-szerződésekről, Gazdaság és Jog, 4. évf. (1996) 5. sz. 14. 
rálásának. Csécsy álláspontjával szemben Miskolczi Bodnár Péter a franchise önálló, sui generis szerződéstípussá válását hangsúlyozta, amely konkrétan meghatározható jellegzetességekkel bír, ${ }^{15}$ és ily módon, bár elismerte mind a definiálás, mind a további tipizálás nehézségeit, nem zárkózott el, sőt szükségesnek tartotta annak esetleges rendszerbe illesztését, törvényi szintű szabályozását.

Vékás Lajos a Ptk. egyes szerződései körének bővítésekor a fö szempontnak azt tekintette, hogy mennyire letisztult az adott jogviszony, megfelelöképpen körvonalazható-e annak fogalma, léteznek-e már olyan fö rögzíthető jellemzők, „sarokelemek”, amelyek lehetővé teszik a szerződések Ptk. szerinti rendszerébe való beillesztését. Vékás egyúttal példaként említette a franchise szerződést, amely - legalábbis az ezredforduló táján - véleménye szerint még nem rendelkezett olyan fogalmi jegyekkel, amelyek elegendőnek bizonyultak volna a típusalkotáshoz, így elvetette annak lehetőségét, hogy a franchise önálló szerződéstípusként az új Ptk. részévé váljon. ${ }^{16}$

A kereskedelmi jellegü, atipikus szerződések Ptk.-ba emelését hasonlóképpen itélte meg az új Ptk. koncepciója, ${ }^{17}$ majd a Szakértői Javaslat is, amely nevesített szerződéstípusként nem tartalmazta sem a faktoring-, sem pedig a lízing- és franchise szerződést, tekintettel arra, hogy az említett szerződések által generált, adott esetben törvénykönyvi szintủ szabályozást igénylő problémák megoldása már meglévő jogintézmények (pl. faktoring esetén az engedményezés, lízing esetén a bérlet) vonatkozó szabályainak alkalmazása útján is lehetséges. ${ }^{18}$

Az atipikus szerződéseket, így különösen a franchise szerződést illetően a Vékásféle álláspont részben még az új Ptk. elfogadott, azonban utóbb hatályba nem lépett normaszövegében is tartotta magát, hiszen a 2009. évi CXX. törvényben a lízing és a faktoring ugyan önáló szerződéstípusként (utóbbi esetén az engedményezés szabályai mögöttességének kimondása mellett) kapott helyet a kódexben, azonban a franchise - onnan kiszorulva - nem nyert nevesítést. A törvény miniszteri indokolása szerint a franchise-megállapodások bonyolultak és tartalmukat tekintve túlságosan sokfélék, így nem rendelkeznek olyan tartalmi maggal, amely a típusképzéshez elengedhetetlenül szükséges. ${ }^{19}$ Mindezeket figyelembe véve tehát elmondható, hogy az új Ptk. hatályba lépése nem érintette volna a franchise szerződések szabályozását, az a gazdasági gyakorlatban továbbra is törvényi szinten nem szabályozott módon maradt volna meg.

Az atipikus szerződések, így különösen a franchise szerződés kodifikálása kérdésében a Kodifikációs Főbizottság által kidolgozott - és a kormányzati honlapon 2012

15 Miskolczı BodnáR Péter: A franchise szerződésekröl, Gazdaság és Jog, 3. évf. (1995) 7-8. sz. 22.

16 VÉKÁs Lajos: Egy új polgári törvénykönyv történelmi időszerüségéröl, Magyar Tudomány, 48. évf. (2001) 12. sz. 1396-1403.

17 1003/2003. (I. 25.) Kormányhatározat az új Polgári Törvénykönyv koncepciójának elfogadásáról, valamint a polgári jogi kodifikációról szóló 1050/1998. (IV. 24.) Korm.-határozat időarányos végrehajtásáról és módosításáról (Megjelent: Magyar Közlöny, 2003. évi 8. szám).

18 VÉKÁs Lajos: Szakértői Javaslat az új Polgári Törvénykönyv tervezetéhez, Complex Kiadó, Budapest, 2008, 65.

19 Miniszteri indokolás a Polgári Törvénykönyvről szóló 2009. évi CXX. törvényhez, 1017. 
februárjában közzétett - szövegtervezet ${ }^{20}$ viszont már egyértelmüen fordulatot hozott, hiszen jelenleg úgy tünik, a lízing-, a faktoring- és a disztribútori szerződés mellett a korábban mellőzésre ítélt franchise is helyet kap majd az új Ptk. szerződéseinek rendszerében.

Érdemes azonban elgondolkodni azon, miért és hogyan kerül be az új Ptk. rendszerébe egy olyan szerződés, amelynek Ptk.-ba illeszthetőségét ezelőtt két-három évvel még egyértelműen elutasították. Tény, hogy a kodifikációs folyamat évtizede alatt a gazdasági viszonyok változtak, fejlődtek. Kérdés azonban, hogy ez a fejlődés eredményezte-e a franchise szerződéssel kapcsolatos főbb jellemzők letisztulását (és ily módon annak kódexbe illeszthetőségét), avagy puszta szemléletváltásról beszélhetünk, különös tekintettel például az európai szerződési jog terén zajló jogegységesítési folyamatra. Úgy gondolom, elsődlegesen a jogviszonyok fejődése tette szükségessé a leendő szabályozás átgondolását, és ily módon a korábbi álláspontok felülvizsgálatát, a szemléletváltást, amelyet azonban az európai jogegységesítési folyamatok felerősítettek. A jogegységesítés részeredményeként 2009-ben publikált közös referenciakeret vázlata (Draft Common Frame of Reference, a továbbiakban DCFR $)^{21}$ ugyanis tartalmaz a franchise szerződésre vonatkozó sajátos rendelkezéseket, és ez talán a Kodifikációs Bizottság tagjainak számára is elegendő indokot szolgáltatott arra, hogy korábbi nézeteiket, álláspontjukat felülvizsgálva kísérletet tegyenek a franchise szerződés fogalmának és legfőbb - típusalkotást lehetővé tevő - jegyeinek meghatározására.

A kodifikációs folyamat alapvetően mindvégig figyelemmel volt az európai jogegységesítési munkálatokra. ${ }^{22}$ Mégis, a franchise kapcsán ez a hatás sokkalta erősebbnek tünik, különösen például arra is tekintettel, hogy az új Ptk. tervezett szövegében a franchise éppen a disztribútori (forgalmazói) szerződés mellett kapott helyet, éppen úgy, ahogyan ez a DCFR rendszerében is látható. Lényeges különbség viszont, hogy a DCFR itt helyezi el az önáló kereskedelmi ügynöki szerződést is, és az említett három szerződésre vonatkozóan rögzít közös rendelkezéseket is, amelyeket az egyes szerződésekre alkalmazandó speciális szabályok követnek, egészítenek ki.

\section{A franchise szabályozása az új Ptk. föbizottsági szövegtervezetében}

Az új Ptk. „legújabb” szövegének, vagyis a Kodifikációs Főbizottság által 2012-ben nyilvánosságra hozott szövegtervezetnek az atipikus szerződéseket illetően csupán egyik újdonsága a franchise szerződés önálló szerződéstípusként való rögzítése, különösen az előzményekre, így a kodifikációs folyamat során kialakult álláspontokra tekintettel. Másrészt viszont, a franchise tervezett Ptk.-ba kerülésével járó megle-

20 http://www.kormany.hu/download/0/d7/70000/Új Polgári Törvénykönyv - a Kodifikációs Főbizottság javaslata - közzétételre.pdf\#!DocumentBrowse (2012. február 15.)

21 Bar, Christian, von - Clive, Eric - Schulte-Nökle, Hans: Principles, Definitions and Model Rules of European Private Law: Draft Common Frame of Reference (DCFR), Outline Edition, 2009, Sellier, München.

22 VÉKÁs Lajos: A DCFR és a magyar polgári jog kodifikációja, Európai Jog, 10. évf. (2010) 1. sz. 3-12. 
pettségünkön túllépve, érdemes némi figyelmet szentelnünk a vonatkozó részletszabályoknak, a definiálásnak és a szabályozás mikéntjének is.

\subsection{A franchise fogalmának meghatározása}

Az új kódex szövegében a franchise „magyarított néven”, jogbérleti szerződésként szerepelne, amely alapján „a jogbérletbe adó védjegy, szerzői és iparjogvédelmi jogok, valamint védett ismeret átengedésére, a jogbérletbe vevő termékeknek, illetve szolgáltatásoknak a védjegy, szerzői és iparjogvédelmi jogok, valamint védett ismeret felhasználásával történő előállitására, illetve értékesitésére és díj fizetésére köteles”. ${ }^{23}$ Mint látható, a cseppet sem egyszerű fogalom megragadja a franchise szerződések oly sokat hangoztatott sokszínűségét, és ezzel egyidejüleg kiemeli annak a szellemi alkotások jogával való szoros kapcsolatát is. ${ }^{24}$ (E tekintetben nagy a hasonlóság a franchise DCFR-ben meghatározott fogalmával is, amelynek szintén alapeleme a szellemi tulajdon körébe eső jogok, know-how és védjegy használata. ${ }^{25}$ ) A fogalom fontos elemét képezi továbbá a „védett ismeret” nevesítése, amelyet a Főbizottság a know-how magyar megfelelőjeként szándékozik az új Ptk. normaszövegébe iktatni. ${ }^{26}$

Más kérdés viszont, hogy a kifejezés magyarítása mennyire felel meg a franchise eredeti tartalmának. Mint arra már korábban is utaltunk, az atipikus szerződések egyik - bár nem törvényszerü - jellemzője a külföldi eredetű név, amelyet a legtöbb esetben nem vagy csak nehezen, az eredeti tartalmat kevésbé jól lefedő módon lehet magyarra fordítani. Éppen ennek köszönhető, hogy e szerződések többségükben az eredeti megnevezésükkel élnek és érvényesülnek a köztudatban, a gazdasági életben. (Történtek ugyan próbálkozások például a lízing kapcsán a „bérletvétel” kifejezés meghonosítására, ${ }^{27}$ azonban ezek nem igazán jártak sikerrel, hiszen a gyakorlatban a mai napig az eredeti, idegen nyelvű megnevezés a használatos.) Részben indokoltnak tartom a Főbizottság azon szándékát, hogy az idegen megnevezésű atipikus szerződéseknek magyar nyelvű megfelelőt találjon. (Hasonló a helyzet a disztribútori szerződéssel, amelyet a Főbizottság szintén magyar megnevezéssel, forgalmazói szerződés néven helyezett el a Ptk. szerződéstípusai között.) Úgy gondolom ugyanakkor, hogy a Főbizottság szándéka szerint a Ptk.-ban szabályozásra kerülő jogbérleti szerződés kifejezés jócskán leszűkíti a franchise eredeti jelentéstartalmát, ily módon korlátok közé szorítva a meglehetősen változatos, és emiatt rugalmas sza-

23 A Kodifikációs Főbizottság javaslata, 6:377. § (1) bekezdés.

24 Csécsy például a franchise szerződést rendszer-licencia szerződésként határozza meg. Lásd: CsÉcsY (2006): i. m., 79.

25 Vö. DCFR, IV. E. - 4:101. „(...) contracts under which one party (the franchisor) grants the other party (the franchisee), in exchange for remuneration, the right to conduct a business (franchise business) within the franchisor's network for the purposes of supplying certain products on the franchisee's behalf and in the franchisee's name, and under which the franchisee has the right and the obligation to use the franchisor's tradename or trademark or other intellectual property rights, know-how and business method."

26 A Kodifikációs Főbizottság javaslata, 2:47. § (2) bekezdés.

27 Lásd például Mıskolczı BodnÁR (1997): i. m., 6. és RÉCzEı László: A lízing a magyar jogban, Gazdaság és Jog, 1. évf. (1993) 12. sz. 5-6. 
bályozást igénylő szerződéses konstrukciót. Igaz ugyan, hogy a franchise esetén dominálnak, sőt egyes esetekben kizárólagosak a használati kötelmi elemek, azonban ezek adott esetben eredmény- és gondossági kötelmi elemmel is kiegészülhetnek, s ez viszont már elegendő ahhoz, hogy kétségbe vonja a szerződés jogbérletként való azonosításának helyénvalóságát.

A magam részéröl indokolhatónak tartom, hogy a magyar polgári jogi kódexben szereplő jogintézmények magyar nevet kapjanak. Nem hiszem ugyanakkor, hogy az ilyen irányú törekvések a gyakorlatban tényleges eredménnyel járnának, hiszen a gazdasági élet szereplői már annyira hozzászoktak az idegen kifejezések használatához (és e kifejezések magyar megfelelőjének hiányához), hogy konkrét jogszabályi rendelkezés mellett sem valószínú, hogy áttérnek egy magyar, azonban a fülnek meglehetősen idegenül csengő kifejezés használatára.

A Kodifikációs Főbizottság szándéka szerint a franchise alanyi körére eddig ,jobb hiján" alkalmazott magyar kifejezéseket (mint franchise-átadó és franchise-átvevő) a jogbérletbe adó és jogbérletbe vevő megnevezések váltanák fel, így tekintettel arra, hogy a franchise fogalmának, illetőleg a felek jogai és kötelezettségei, valamint a szerződés egyéb jellemzői vizsgálatának alapjául az említett főbizottsági javaslat szolgál, a továbbiakban én magam is ezeket a kifejezéseket használom.

A föbizottsági javaslatban a franchise definiálása - a Ptk. jelenlegi gyakorlatához hasonló módon - a szerződés tartalmának a meghatározásával történik. Érdekesség azonban, hogy míg a Ptk. az egyes szerződéstípusok fogalmi elemeiként hagyományosan a felek fő jogosultságát és kötelezettségét tartalmazza, addig a franchise esetén ez pusztán kötelezettségek formájában jelenik meg, hiszen a normaszöveg a jogbérletbe adó oldalán meghatározott jogosultságok átengedésének kötelezettségét, a jogbérletbe vevő oldalán pedig előállítási, értékesítési és díffizetési kötelezettséget rögzít. A franchise fogalmának ilyetén meghatározása véleményem szerint helytelen, tekintettel arra, hogy az előállitás és értékesítés a jogbérletbe vevő oldalán nemcsak kötelezettségként, hanem azzal egyidejüleg jogosultságként is jelentkezik. Ezzel cseng össze a korábban már hivatkozott DCFR vonatkozó rendelkezése is, amely szerint a franchise-átvevő (jogbérletbe vevő) egyidejü joga és kötelezettsége a franchise-átadó (jogbérletbe adó) védjegyének vagy más szellemi alkotáshoz füződő jogának, know-how-jának használata. Hasonlóképpen, a Magyar Franchise Szövetség által iránymutató alapdokumentumként elfogadott Etikai Kódex is jog és kötelezettség egyidejü fennállását rögzíti. ${ }^{28}$ Megjegyzendő, hogy a kötelezettségek rögzítése nemcsak a definiálást, hanem a szerződés tartalmának további meghatározását is jellemzi.

\subsection{A franchise alanyai, jogok és kötelezettségek}

A franchise fogalmából kiindulva annak alanyai a jogbérletbe adó és a jogbérletbe vevő. A jogbérletbe adó fö kötelezettsége egy vagy több meghatározott, a szellemi tulajdon körébe eső jogosultság használatának átengedése („licenciaelem”), amely

${ }^{28}$ Franchising Etikai Kódex, http://www.franchise.hu/index.php?hir=16 (2012. február 16.). 
mint közvetett tárgyra, irányulhat akár védjegyre, védett ismeretre (know-how-ra) vagy egyéb szerzői jogi, iparjogvédelmi jogosultságra. A jogbérletbe vevő kötelezettsége (és egyben jogosultsága is) a jogbérletbe adó védjegyének időleges használata, egyéb jogosultságának hasznosítása, oly módon, hogy termékeket vagy szolgáltatásokat állít elő, ezeket értékesíti, cserébe pedig - a szerződés visszterhes jellegére tekintettel - dijat fizet. A használat jogához kapcsolódóan ugyanakkor mellőzi azt a kérdést, hogy van-e lehetőség a használati jogosultság továbbadására. Minthogy a gyakorlatban a franchise keretében átadott jogosultságok továbbadása ismert, mindenképpen szükséges lenne, hogy a javaslat akár e lehetőség kizárását, akár a továbbadás engedélyhez kötését rögzítse.

A szerződés további lényeges eleme, hogy a jogbérletbe vevő saját nevében és saját érdekében jár el, ${ }^{29}$ vagyis bár a jogbérletbe adó védjegyét és jogosultságát használja, az elóállított termékek és szolgáltatások értékesítéséből származó bevétel őt, és nem a jogbérletbe adót illeti. Az elő́llítás kapcsán ugyanakkor érdemes megjegyezni, hogy a termék előállításához szükséges alapanyagot a jogbérletbe vevő a jogbérletbe adótól, illetőleg az általa megjelölt személytől köteles beszerezni. Ez alól csak az az eset képez kivételt, ha a jogbérletbe adó az említett kötelezettségét nem teljesíti. llyenkor a jogbérletbe vevő jogosult az alapanyagot máshonnan beszerezni. Ugyanez a szabály vonatkozik a jogbérletbe vevő által értékesíteni kívánt (de nem általa elöállítandó) termékekre is.

A föbizottsági javaslat a szellemi tulajdon körébe eső jogosultságok átengedéséhez és használatához, hasznosításához kapcsolódóan mindkét fél oldalán további kötelezettséget is rögzít, amely a jogbérletbe adó oldalán sajátos jogszavatossági jellegủ kötelezettség formájában jelenik meg. Noha a javaslat a szavatosság kifejezést nem tartalmazza, a ,jogok folyamatos és zavartalan gyakorlásának biztosítása” fordulat arra utal, hogy a jogbérletbe adó szavatol azért, hogy másnak nem áll fenn olyan joga, amely az adott jogosultság hasznosítását akadályozná vagy korlátozná, ezzel megzavarva a jog folyamatos gyakorlását.

Jellegét tekintve tehát a kötelezettség jogszavatossági, kérdés viszont, hogy alkalmazhatók-e, és ha igen, úgy milyen mértékben a jogszavatosságra vonatkozó jogszabályi rendelkezések, hiszen erre nézve a javaslat nem ad semmilyen iránymutatást. A franchise szerződés - tartalmát tekintve - erős használati kötelmi jelleggel bír. A Ptk.-ban szabályozott bérleti szerződés esetén a jogalkotó rögzíti a bérbeadó jogszavatossági kötelezettségét, ${ }^{30}$ és hasonlóképpen rendelkezik a szabadalom hasznosítására kötött szerződés kapcsán a szabadalmi törvény ${ }^{31}$ és a védjegytörvény ${ }^{32}$ is, amelyek visszautalnak a Ptk.-ra, és a szerződésre az eladónak a tulajdonjog átruházásáért való szavatosságára irányadó szabályokat rendelik alkalmazni azzal, hogy a hasznosító elállás helyett a szerződést azonnali hatállyal felmondhatja. ${ }^{33}$ Úgy gondolom, a jövőben a franchise szerződésre vonatkozó joganyagnak is ki kell egé-

29 A Kodifikációs Főbizottság javaslata, 6:377. § (2) bekezdés.

30 Ptk. 425. § (2) bekezdés.

31 1995. évi XXXIII. törvény a találmányok szabadalmi oltalmáról.

1997. évi XI. törvény a védjegyek és földrajzi árujelzők oltalmáról.

Sztv. 28. $\S(1)$ bekezdés, Védjegytörvény 24 . $§(1)$ bekezdés. 
szülnie az említett szabállyal, helyesebb lenne, ha a jogalkotó az említett terminológiát átvéve - és ezzel a szerződések közötti összhangot megőrizve - rögzítené a franchise átadójának, vagyis a jogbérletbe adónak a jogszavatossági kötelezettségét.

$A$,jogok folyamatos és zavartalan gyakorlásának biztosítása” kifejezés ugyanakkor túlmutat a jogszavatossági tartalmon, amennyiben utal arra is, hogy a jogbérletbe adó a franchise időtartama alatt köteles a szerződés alapjául szolgáló szellemi alkotásra vonatkozó oltalom fenntartására, így például a fenntartási díj rendszeres megfizetésére is.

A jogbérletbe vevő oldalán külön kötelezettségként jelenik meg a jog megóvása, ami a jogbérletbe adó által létrehozott hálózat és az értékesített termékek és szolgáltatások jó hírneve megóvásának kötelezettségével egészül ki. ${ }^{34}$ Hiányosságnak tekintem ugyanakkor, hogy a javaslat egyáltalán nem ír elő a jogbérletbe vevő számára titoktartási kötelezettséget, holott ez a jogbérletbe adó érdekét szolgálná, s rögzítése lényeges lenne nemcsak a szerződés fennállásának idejére, hanem azt követően is.

A számos kötelezettség mellett a franchise föbizottsági javaslatában foglalt szabályai jogosultságot is rögzítenek. Valamennyi - nevesített és nevesítetlen - jogosultság közül kiemelést érdemel a jogbérletbe adó utasítási joga, amely megilleti egyrészt a termék vagy szolgáltatás értékesítésével, másrészt a hálózat és a jó hírnév megóvásával kapcsolatosan is. ${ }^{35}$ A jogbérletbe adó utasítási jogára vonatkozóan a javaslat bevezetné a célszerűtlen vagy szakszerütlen utasítás vállalkozási, illetőleg megbízási szerződésnél jól ismert szabályának ${ }^{36}$ alkalmazását, és az ilyen utasításhoz kapcsolódóan figyelmeztetési kötelezettséget is előírna a jogbérletbe vevő részére. Eltérés viszont a vállalkozási szerződésre vonatkozó Ptk.-beli rendelkezéshez képest, hogy abban az esetben, ha a jogbérletbe adó a figyelmeztetés ellenére továbbra is fenntartja utasítását, azt a jogbérletbe vevő köteles teljesíteni, vagyis nincs lehetőség a szerződés egyoldalú megszüntetésére. A jogbérletbe vevő ugyanakkor az utasítás teljesítéséből eredő kár megtérítésére nem köteles, azért a jogbérletbe adó felel. Hiányossága ugyanakkor a franchise-ra vonatkozó rendelkezéseknek, hogy nem tartalmaznak jogkövetkezményt arra az esetre, ha a jogbérletbe vevő figyelmeztetési kötelezettségét elmulasztja. A vállalkozási szerződés esetén a figyelmeztetés elmulasztásából eredő kárért a vállalkozó felelős. ${ }^{37}$ Úgy gondolom, hasonlóképpen rögzíthető lenne a felelősség ezen formájának meghatározása a franchise esetén is.

A figyelmeztetésen túl a főbizottsági javaslat az utasítás teljesítése megtagadásának kötelezettségét írja elő a jogbérletbe vevő számára abban az esetben, ha az utasítás végrehajtása jogszabály vagy hatósági határozat megsértéséhez vezetne, vagy mások személyét, illetőleg vagyonát veszélyeztetné. ${ }^{38}$

34 A Kodifikációs Főbizottság javaslata, 6:380. §.

35 Az utasítás joga a tevékenység kifejtésére irányuló szerződések esetén jellemző. A franchise esetén is rögzítené ezt a jogot a Ptk., ami pedig bizonyítja, hogy maga is elismeri, hogy a franchise nem tisztán használati kötelmi jellegü, hanem eredménykötelmi és gondossági kötelmi elemeket egyaránt tartalmaz. Ebben az esetben viszont a jogbérlet megnevezés használata nem helytálló!

36 Ptk. 392. § (1) és (3) bekezdés, 476. §.

37 Ptk. 392. § (2) bekezdés.

38 Vö. Ptk. 493. § (4) bekezdés. 
A jogbérletbe adó a szerződésben és az utasításaiban foglaltak teljesítését ellenőrizheti (ellenőrzési jog). Az említett joghoz kapcsolódóan ugyanakkor a javaslat további rendelkezést nem tartalmaz, sem az ellenőrzés esetleges elmulasztására, sem pedig a jog gyakorlásának módjára vonatkozóan.

\subsection{A szerződés megszünése}

A föbizottsági javaslat szerint a franchise szerződés köthető akár határozott, akár határozatlan időtartamra. A határozott időre megkötött szerződés a meghatározott idő leteltével megszűnik, határozatlan időre kötött szerződés esetén - tekintettel a szerződés használati kötelmi jellegére, ennek köszönhető irreverzibilitására -, felmondásra van lehetőség. A felmondás jogával bármelyik fél élhet, a naptári hónap utolsó napjára. A felmondási idő a szerződés első évében egy hónap, második évében két hónap, harmadik évében és azt követően három hónap, vagyis a felmondási idő a szerződés időtartamával arányosan nő. Amint az jól látható, a javaslat szövege a felmondás kapcsán a kereskedelmi ügynöki szerződés felmondására vonatkozó rendelkezéseket veszi át, ${ }^{39}$ amelyeket a Kodifikációs Főbizottság vélhetően a jogviszonyok hasonlóságára (pl. tartósság, bizalmi elem stb.) tartott helytállónak. A felmondási időre vonatkozóan ugyanezzel a szabállyal találkozunk a javaslatnak a tartós közvetítői szerződésre vonatkozó szabályai között, amely ugyanakkor kiegészül azzal is, hogy a felek az imént említett felmondási időnél rövidebb időt nem állapíthatnak meg, az a kikötés semmisségét vonja maga után. Ebböl a szempontból tehát megfontolandó e rendelkezés alkalmazása a franchise szerződés körében is, hiszen amennyiben a cél az, hogy a jogviszony tartósságára tekintettel hosszabb legyen a felmondási idő is, úgy indokolatlan - és a szabályozás céljával ellentétes - lenne az a megoldás, ha a felek akár egy ötéves franchise megállapodás esetén is megállapodhatnának egy rövidebb határidőben.

A franchise (jogbérleti) szerződés felmondásához kapcsolódóan további hiányosságnak tartom, hogy a javaslat nem tesz különbséget rendes és rendkívüli felmondás között, és egyáltalán nem tér ki a felmondás indokolásának kötelezettségére sem.

A jogbérleti szerződés megszűnésével a jogbérletbe vevőnek a szellemi tulajdon körébe eső jogosultságok használatára vonatkozó jogosultsága is automatikusan megszünik. Úgy vélem, a használati jogosultság megszünésének külön történő rögzítése felesleges, hiszen éppen e jogosultság használatának átengedése képezi a jogbérleti szerződés tárgyát. A szerződés megszűnése maga után vonja, hogy a jogbérletbe vevő a továbbiakban nem gyakorolhatja azokat a jogosultságokat (jelen esetben a szellemi tulajdon körébe eső jogok használatát), amelyek őt a szerződés alapján illetnék meg. A szerződéssel pusztán a jogok gyakorlásának, például a védjegy használatának átengedése és nem annak végleges átruházása történt, így nincs szükség a jogosultság megszünésének külön történő rögzítésére.

39 Vö. 2000. évi CXVII. törvény az önálló kereskedelmi ügynöki szerződésről, 16. § (2) bekezdés. 


\section{4. Összegzés}

A 2009-es Ptk. elfogadását, majd hatályba nem lépését követően gyakorlatilag sub rosa zajló kodifikációs folyamat eredményeként 2012 februárjában megjelent föbizottsági javaslat számos meglepetéssel szolgált a folyamatot már hosszú évek óta nyomon követő szakmai közönség számára. A 2009-es Ptk. megszületését megelöző időszak tendenciáit figyelembe véve ilyen meglepetésnek tünik a lízing- és faktoringszerződés mellett a franchise szabályainak a Ptk.-ba iktatása.

Az előbbi néhány oldalon a tipikus és atipikus szerződések közötti határvonal megvonásával és az egyes atipikus szerződések Ptk.-ba illesztésével kapcsolatos nehézségek, problémák áttekintését követően, a franchise szerződés föbizottsági javaslatba illesztett, nóvumként megjelenő szabályanyagát vizsgáltam meg közelebbröl.

Mint látható, az új Ptk. kísérletet tenne arra, hogy a franchise kifejezés helyett meghonosítsa a ,jogbérleti szerződés” fogalmát, és azt önálló szerződéstípusként így helyezze el a Ptk. egyes szerződéseinek rendszerén belül. Habár az atipikus szerződések kodifikálását illetően mai napig elhangzanak érvek és ellenérvek, elmondható, hogy a franchise-ra vonatkozó szabályanyag kodifikálása mára már egyértelműen időszerű és szükséges. Más kérdés viszont a megvalósítás mikéntje, hiszen egy olyan szerződés definiálása, amely egyidejüleg hordoz használati kötelmi és tevékenység kifejtésére irányuló szerződési elemeket, különös figyelmet és körültekintést érdemel; akárcsak a szerződés tartalmát képező jogok és kötelezettségek meghatározása, melynek során tekintettel kell lenni a szerződés alapjául szolgáló, a szellemi tulajdon körébe eső jogosultságok speciális szabályaira.

Úgy vélem, a franchise szabályanyagának kialakítása során támpontot jelenthetnének a licenciaszerződésre vonatkozó szabályok, hiszen a franchise alapját is egyfajta licenciaadás jelenti, amelyet kiegészítenek a termék, illetve szolgáltatás előállítására vonatkozó szabályok, ily módon egy egységesebb és a kapcsolódó iparjogvédelmi jogszabályokkal való összhangot garantáló szabályanyag jöhetne létre.

\section{Abstract}

The introductory part of the study presents the standing points related to the delimitation of typical and atypical contracts. The first part gives an overview of the debates on the integration of atypical contracts (e.g. leasing, factoring, franchise, etc.) into the Hungarian Civil Code with special regard to the fact that the proposal on the new Civil Code contains regulations on franchise contracts. The second part examines the rules on franchise contracts of the proposal which was elaborated by the Codification Committee and published in February 2012. 